\title{
Influence of environmental pollution with creosote oil or its vapors on biomass and selected physiological microorganisms groups of
}

\author{
Teresa Krzyśko-Łupicka ${ }^{1,{ }^{*}}$, Krystyna Cybulska ${ }^{2}$, Paweł Kołosowski ${ }^{2}$, Arkadiusz Telesiński ${ }^{2}$ \\ and Adam Sudot $^{1}$ \\ ${ }^{1}$ University of Opole, Faculty of Natural Sciences and Technology, ul. Kominka 6a, 45-092 Opole, \\ Poland \\ ${ }^{2}$ West Pomeranian University of Technology Szczecin, Faculty of Environmental Management and \\ Agriculture, ul. Słowackiego 17, 71-434 Szczecin, Poland
}

\begin{abstract}
Survival of microorganisms in soils from treatment facility and landfill of wooden railway sleepers contaminated with creosote oil as well as in two types of soils with different content of organic carbon, treated with creosote oil vapors, was assessed. Microbiological assays including determination of: the biomass of living microorganisms method and the number of proteolytic, lipolytic and amylolytic microorganisms were carried out under laboratory conditions. Chromatography analysis of the soil extract from railway sleepers treatment facility was performed using GC/MS. The highest biomass and the number of tested microorganisms were determined in soils from wooden railway sleepers landfill, while the lowest in soil from the railway sleepers treatment facility. Vapors of creosote oil, regardless of the soil type, significantly increased only the number of lipolytic bacteria.
\end{abstract}

\section{Introduction}

Development of railways in Poland is not only associated with investments in more and more modern fleet, but also with the maintenance of an adequate standard of railway lines. Achieving this goal requires incurring expenditures on production and subsequent utilization of used railway sleepers needed for the construction of railway tracks. A particular environmental problem is caused by treatment and storage of wooden sleepers impregnated with creosote oil [1].

Creosote oil, also known as the impregnation oil, is a mixture of products derived from the distillation of coal tar and boiling at $200-360^{\circ} \mathrm{C}$ temperatures [2]. It is a mixture of hundreds of compounds, of which only a small fraction (less than $20 \%$ ) is present in an amount exceeding 1\%. One of the most important groups of compounds forming the creosote oil structure are aromatic hydrocarbons, including polycyclic aromatic

\footnotetext{
*Corresponding author: teresak@uni.opole.pl
} 
hydrocarbons (PAHs). Compounds in the creosote oil are characterized by high durability and ability to bioaccumulation [3,4], which not only causes changes in the surrounding environment, but also threatens the health of humans and animals leading to increased cancer incidence [5]. Highly toxic effect of these substances on plants was also confirmed $[1]$.

Legislation on the composition of creosote oil is not uniform in different parts of the world. Creosote oil used to impregnate the wood is classified according to the AWPA (American Wood-Preservers' Association) as of P1 and P2 types, while according to WEI (Western European Institute for Wood Preservation) as types: A, B and C. In Europe, only $\mathrm{B}$ and $\mathrm{C}$ types are approved for use now. They differ with physicochemical properties, which may affect the impregnation process quality and the way of the treatment [6].

In Poland, there are lot of areas contaminated with creosote oil as a result of its penetration into the soil and water from the long operating sleeper treatment facilities, or factories involved in wood impregnation. These post-industrial areas are also abundant in PCBs, benzene, toluene, and mineral oils.

Creosote oil is a substance difficult to recycle due to its low solubility in water and its removal from the environment is usually expensive and often ineffective. From contaminated areas, it is removed by physical, chemical or biological means. One method may be bioremediation, which consists of the controlled and supported activity of microorganisms using the hydrocarbon contamination as a source of carbon and energy [7]. There have been many studies on the degrading abilities of microorganisms for the disposal of toxic components of creosote oil, when searching for the most efficient method of environment cleaning. Robak et al. [8] indicated that high assimilation capacity in relation to the hydrocarbons are shown by yeast of Yarrowia lipolytica. However, after the period of bioremediation, very different results of reducing their concentration in the soil from $11 \%$ to $70 \%$ of the initial content, were achieved. The method of soil bioremediation in situ using eukaryotic microorganisms contributes to a remarkable reduction in the amount of petroleum hydrocarbons contained in the soil and the use of Yarrowia lipolytica strains speeds up the cleaning process [9].

Experiments by Sabate et al. [10] have shown the opportunities to biodegrade of creosote oil components by microorganisms present in the soil. They allow to get more effective degradation of compounds in the soil; not only those derived from creosote oil, as well as other contaminants arising from industrial production processes.

Due to the threat posed to the surrounding environment by creosote oil, to understand the biotic relationships within a contaminated environment is a must.

The aim of the study was to evaluate the survival of microorganisms in soils from treatment facility and landfill of wooden railway sleepers contaminated with creosote oil and in two types of soils with different content of organic carbon, treated with creosote oil vapors.

\section{Materials and methods}

The research material consisted of soil samples from the treatment facility and landfill of railway sleepers as well as soils collected from the topsoil of uncontaminated areas in the West Pomeranian province in:

- Lipnik - granulometric composition of loamy sand and organic carbon content at the level of $0.87 \%$,

- Ostoja - light loam with organic carbon content $1.10 \%$.

Both types of soil were treated with creosote oil vapors from crushed wooden railway sleepers. For this purpose, $500 \mathrm{~g}$ of the soil was sealed for 21 days in desiccators with 
fragmented railway sleepers. The control sample consisted of untreated soil not subjected to vapor treatment.

Microbiological assays were performed in laboratory including determination of:

- biomass of living microorganisms by means of physiological method by Anderson and

Domsch using Ultragas U4S analyzer [11]. The amount of living microorganisms biomass recalculated onto $\mathrm{g}^{-1} \mathrm{DM}$ soil was achieved from the equation (1):

$$
x=40.4 y+0.37
$$

where: $x$ - amount of $\mathrm{C}$ contained in the biomass of living microorganisms [mg C $\cdot \mathrm{g}^{-1} \mathrm{DM}$ soil]; $\mathrm{y}$ - maximum initial $\mathrm{CO}_{2}$ production $\left[\mathrm{cm}^{3} \cdot \mathrm{h}^{-1} \cdot \mathrm{g}^{-1} \mathrm{soil}\right]$.

- number of microorganisms: proteolytic (LMP) on Frazier's medium, lipolytic (LML) on the medium with tributyrin, and amylolytic (LMA) on Waksman's medium [12] by means of Koch's decimal dilutions culture method. The cultures were incubated at $22-25^{\circ} \mathrm{C}$ for 3 to 7 days. The number of microorganisms are given as colony forming units (CFU) recalculated onto 1 gram of dry matter $(\mathrm{DM})\left[\mathrm{CFU} \cdot \mathrm{g}^{-1} \mathrm{DM}\right]$.

At the same time, chemical analysis of averaged soil sample from railway sleepers treatment facility was performed applying GC/MS technique [13, 14].

The results were processed using one-way variance analysis (ANOVA) in Statistica 10 software applying Duncan's test.

\section{Discussion}

The number and activity of physiological groups of microorganisms in soils from the treatment facility and landfill of wooden railway sleepers as well as soils treated with creosote oil vapor, was varied (Fig. 1). The highest biomass of live microorganisms amounting to $15.3 \mathrm{mg} \mathrm{C} \mathrm{g}^{-1}$ was determined in the soil from the landfill of railway sleepers, but it did not significantly differ from the microbial biomass determined in the soil from the Ostoja. In contrast, it was significantly higher than that in soil from Lipnik. Achieved results suggest that creosote oil in soil from the railway sleepers landfill had no significant effect on the amount of biomass.

The lowest biomass of living microorganisms of approximately $7 \mathrm{mgCg}^{-1}$ was recorded in soil from the railway sleepers treatment facility; it was almost by $50 \%$ lower as compared to the biomass determined in soil from the railway sleepers landfill and soil from Ostoja.

It is worth noting that the creosote oil vapors, as compared to the control, did not affect the biomass of living microorganisms in the soils from Ostoja and Lipnik.

The tested samples were similar in terms of the number of proteolytic and amylolytic microorganisms, while varied with the number of lipolytic microorganisms.

The highest number of proteolytic microorganisms was determined in the soil from the railway sleepers landfill, which was similar to that in the Ostoja soil exposed to vapors, as well as in control. The lowest number of proteolytic-activity microorganisms was determined in the soil from the sleeper treatment facility $\left(4.0 \cdot 10^{3} \mathrm{CFU} \cdot \mathrm{g}^{-1} \mathrm{DM}\right)$. Creosote oil vapors, as compared to the control, did not affect the number of proteolytic microorganisms in the tested soils from Ostoja and Lipnik (Fig. 2). 


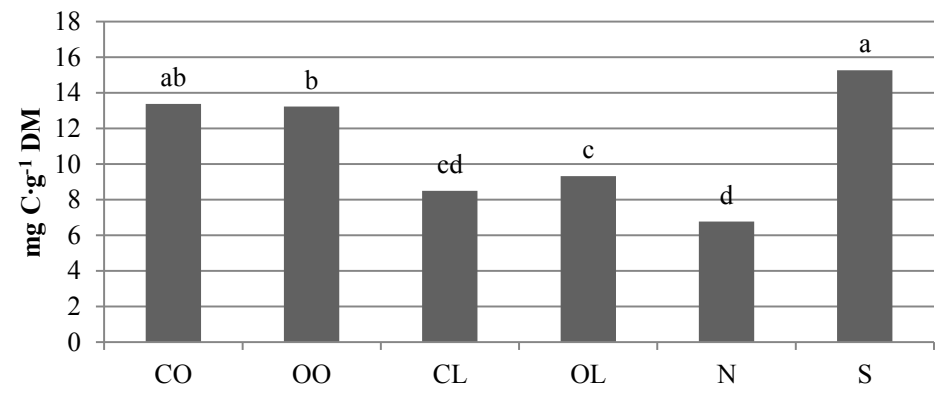

Fig. 1. Biomass of living microorganisms $\left(\mathrm{mg} \mathrm{C} \cdot \mathrm{g}^{-1} \mathrm{DM}\right)$ in soils from the treatment facility and landfill of railway sleepers as well as soils subject to the creosote oil vapors treatment. $\mathrm{CO}$ - soil from Ostoja (control); $\mathrm{OO}$ - soil from Ostoja subject to the creosote oil vapor treatment; CL - soil from Lipnik (control); $\mathrm{LO}$ - soil from Lipnik subject to the creosote oil vapors treatment; $\mathrm{N}$ - soil from the railway sleepers treatment facility; $\mathrm{S}$ - soil from the railway sleepers landfill treated with the creosote oil. a, b..d -values denoted with the same letters do not differed statistically $(\mathrm{P}<0.05)$.

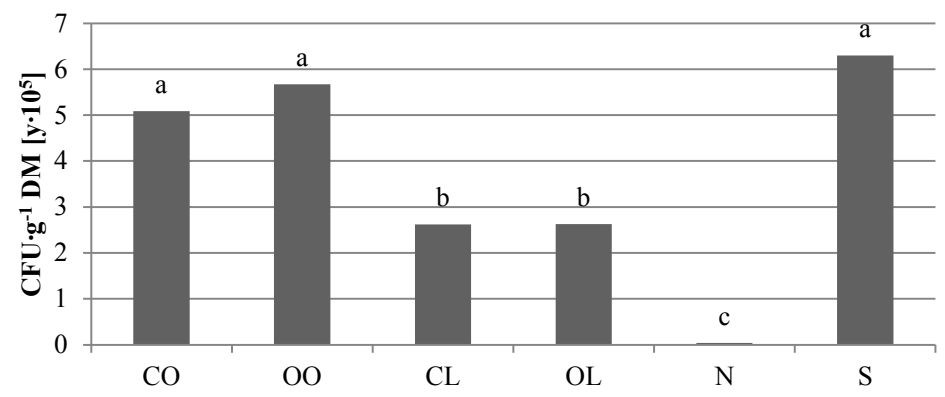

Fig. 2. Number of proteolytic microorganisms (LMP) $\left[\mathrm{CFU} \cdot \mathrm{g}^{-1} \mathrm{DM}\right.$ of soil] in soils from the railway sleepers treatment facility and landfill as well as soils subjected to creosote oil vapors treatment. $\mathrm{CO}$ - soil from Ostoja (control); $\mathrm{OO}$ - soil from Ostoja subject to the creosote oil vapor treatment; $\mathrm{CL}$ - soil from Lipnik (control); LO - soil from Lipnik subject to the creosote oil vapors treatment; $\mathrm{N}$ - soil from the railway sleepers treatment facility; $\mathrm{S}$ - soil from the railway sleepers landfill treated with the creosote oil. a, b...d - values denoted with the same letters do not differed statistically $(\mathrm{P}<0.05)$.

A similar trend in the microorganisms number oscillation was recorded for amylolytic activity. Significantly the highest number $\left(7.8 \cdot 10^{5} \mathrm{CFU} \cdot \mathrm{g}^{-1} \mathrm{DM}\right)$ was determined in soil from the railway sleepers landfill, whereas the lowest in the soil from railway sleeper treatment facility. Creosote oil vapors, as compared to the control, significantly stimulated (by 32\%) development of microorganisms showing amylolytic activity in the loamy soil from Lipnik. In contrast, they had no significant effect on the number of these microorganisms in sandy soil from Ostoja. 


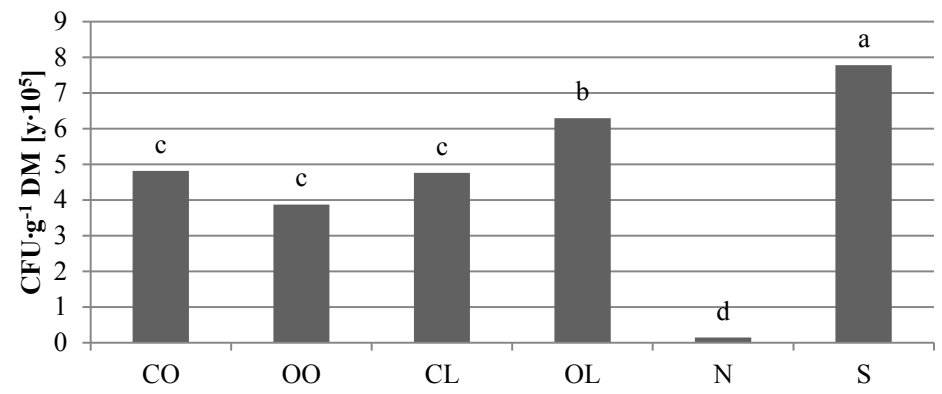

Fig. 3. Number of amylolytic microorganisms (LMA) $\left[\mathrm{CFU} \cdot \mathrm{g}^{-1} \mathrm{DM}\right.$ of soil] in soils from the railway sleepers treatment facility and landfill as well as soils subjected to creosote oil vapors treatment. $\mathrm{CO}$ - soil from Ostoja (control); $\mathrm{OO}$ - soil from Ostoja subject to the creosote oil vapor treatment; $\mathrm{CL}$ - soil from Lipnik (control); $\mathrm{LO}$ - soil from Lipnik subject to the creosote oil vapors treatment; $\mathrm{N}$ - soil from the railway sleepers treatment facility; $\mathrm{S}$ - soil from the railway sleepers landfill treated with the creosote oil. a, b....d - values denoted with the same letters do not differed statistically $(\mathrm{P}<0.05)$.

The lipolytic-activity was shown by the most numerous group of physiological microorganisms in the tested samples. Their averaged number in analyzed samples was three times higher than the amylolytic bacteria and approximately 7 times higher than proteolytic microorganisms.

Significantly the highest number of lipolytic microorganisms $\left(2.4 \cdot 10^{6} \mathrm{CFU} \cdot \mathrm{g}^{-1} \mathrm{DM}\right)$ was determined in the soil from railway sleepers landfill and loamy soil from Lipnik subjected to the creosote oil vapors treatment $\left(2.110^{6} \mathrm{CFU} \cdot \mathrm{g}^{-1} \mathrm{DM}\right)$, while the lowest number of these microorganisms was determined in soil from the treatment facility $\left(2.5 \cdot 10^{4} \mathrm{CFU} \cdot \mathrm{g}^{-1} \mathrm{DM}\right)$, i.e. 55 -fold less than average value for all tested samples. There was a significant increase in the number of lipolytic microorganisms in sandy soil from Lipnik treated with creosote oil vapors, as compared to the control. However, their numbers were at a similar level to that in the loamy soil from Ostoja (control).

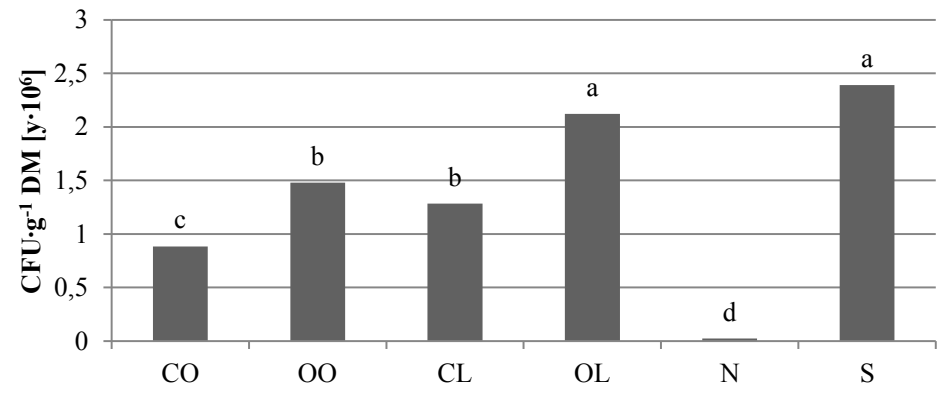

Fig. 4. Number of lipolytic microorganisms (LML) [CFU.g-1 DM of soil] in soils from the railway sleepers treatment facility and landfill as well as soils subjected to creosote oil vapors treatment. $\mathrm{CO}$ - soil from Ostoja (control); $\mathrm{OO}$ - soil from Ostoja subject to the creosote oil vapor treatment; CL - soil from Lipnik (control); LO - soil from Lipnik subject to the creosote oil vapors treatment; $\mathrm{N}$ - soil from the railway sleepers treatment facility; $\mathrm{S}$ - soil from the railway sleepers landfill treated with the creosote oil. a.....d - values denoted with the same letters do not differed statistically $(\mathrm{P}<0.05)$.

The lowest level of all investigated microbiological indicators was recorded in the soil from the railway sleeper treatment facility, indicating that it is a hostile environment for microorganisms. Chemical analysis showed that the $\mathrm{pH}$ of the soil was strongly acidic 
(pH 4.1), and creosote oil content was $1183 \mathrm{mg} / \mathrm{kg} \mathrm{DM}$, including $672 \mathrm{mg} / \mathrm{kg} \mathrm{DM}$ of PAHs and $511 \mathrm{mg} / \mathrm{kg} \mathrm{DM}$ of n-aliphatic hydrocarbon with C8-C40 chain length. Presence of aliphatic and polycyclic aromatic hydrocarbons (PAHs), and particularly high concentration of benzo(a)pyrene (62 mg/kg DM) and benzo(k)fluoranthene $(175.3 \mathrm{mg} / \mathrm{kg} \mathrm{DM})$, leads to a biological imbalance as the result of an increase in the amount of organic carbon with the deficit of available forms of nitrogen and phosphorous necessary for the development of microorganisms (Table 1).

Table 1. Quantitative and qualitative composition of polycyclic aromatic hydrocarbons (PAHs) and $\mathrm{C} 8-\mathrm{C} 40 \mathrm{n}$-aliphatic hydrocarbons in soil from the railway sleepers treatment facility

$\left[\mathrm{mg} \cdot \mathrm{kg}^{-1} \mathrm{DM}\right]$.

\begin{tabular}{|c|c|c|c|}
\hline \multicolumn{2}{|c|}{ WWA [mg $\left.\cdot \mathbf{~ k g}^{-\mathbf{1}} \mathbf{D M}\right]$} & \multicolumn{2}{c|}{ n-alkany $(\mathbf{C 8}-\mathbf{C 4 0})\left[\mathbf{m g} \cdot \mathbf{k g}^{-\mathbf{1}} \mathbf{D M}\right]$} \\
\hline Compound & Amount & Compound & Amount \\
\hline Naphtalene & 0.1 & $\mathrm{C} 8$ & 0.0 \\
\hline Acenaphtylene & 0.0 & $\mathrm{C} 10$ & 0.2 \\
\hline Acenaphten & 0.5 & $\mathrm{C} 12$ & 0.6 \\
\hline Fluorene & 28.1 & $\mathrm{C} 14$ & 28.8 \\
\hline Fenantrene & 46.0 & $\mathrm{C} 16$ & 14.1 \\
\hline Anthracene & 132 & $\mathrm{C} 18$ & 149.7 \\
\hline Fluorantene & 84.6 & $\mathrm{C} 20$ & 10.0 \\
\hline Pyrene & 4.8 & $\mathrm{C} 22$ & 80.9 \\
\hline Benzo(a)anthracene & 5.7 & $\mathrm{C} 24$ & 28.8 \\
\hline Chryzene & 88.8 & $\mathrm{C} 26$ & 11.4 \\
\hline Benzo(b)fluoranthene & 0.0 & $\mathrm{C} 28$ & 18.8 \\
\hline Benzo(k)fluoranthene & 175.3 & $\mathrm{C} 30$ & 114.8 \\
\hline Benzo(e)pyrene & 0.0 & $\mathrm{C} 32$ & 4.9 \\
\hline Benzo(a)pyrene & 61.9 & $\mathrm{C} 34$ & 2.8 \\
\hline Indeno(1,2,3-cd)pyrene & 43.9 & $\mathrm{C} 36$ & 1.7 \\
\hline Dibenzo(a,h)anthracene & 0.0 & $\mathrm{C} 38$ & 0.6 \\
\hline Benzo(g,h,i)perylene & 0.0 & $\mathrm{C} 40$ & 43.0 \\
\hline Summary & $\mathbf{6 7 1 . 7}$ & & $\mathbf{5 1 1 . 4}$ \\
\hline
\end{tabular}

\section{Results}

Creosote oil, due to its antiseptic properties, is commonly used as a impregnating substance to protect wooden elements used in industry, such as railway sleepers, fragments of bridges, coastal infrastructure, traction poles, ship hulls, log houses and fences, playground and yards. Components of creosote oil adversely affect the fundamental ecological functions of the soil: lead to the transformation in quantitative and qualitative composition of microorganism populations; inhibit the growth, photosynthesis and respiratory processes at plants; and also have direct and indirect impact on animal and human organisms.

Many studies indicate mutagenic and toxic properties of creosote oil components [15]. Chemically, the creosote oil is a mixture of compounds such as aliphatic hydrocarbons, aromatic hydrocarbons, PAHs, heterocyclic compounds containing sulfur, oxygen, nitrogen, and carboxyl group [16]. PAHs have mutagenic and carcinogenic action to humans and plants, as well as aquatic and land animals [17]. Aromatic amines are also toxic as they are rapidly absorbed through the skin. In turn, nitrogen heterocyclic compounds, e.g. quinoline, due to the high water solubility, can lead to its contamination [18].

Substances with high volatility contained in the creosote oil also pose a threat to the environment, because they are difficult to eliminate. The vapor pressure of the individual oil components is from $12700 \mathrm{~Pa}$ for benzene to $2.0 \cdot 10^{-10} \mathrm{~Pa}$ for dibenzoanthracene [19]. 
Populations of microorganisms living within the soil can utilize a dose of PAHs as a carbon or energy source, converting them into biomass, water and $\mathrm{CO}_{2}$. The formation of biologically inaccessible oxidized metabolites and PAHs fractions was documented by [10]. As expected by other researchers [20,21], biomass of living organisms in contaminated soil and ground within the railway sleepers landfill, also increased. This fact was confirmed by our findings, since the highest biomass and number of proteolytic, amylolytic and lipolytic microorganisms were also determined in soils from the landfill of timber railway sleepers, despite the presence considerable amounts of benzo(k)fluoranthene $\left(175.3 \mathrm{mg} \cdot \mathrm{kg}^{-1} \mathrm{DM}\right)$ and benzo(a)pyrene $\left(62 \mathrm{mg} \cdot \mathrm{kg}^{-1} \mathrm{DM}\right)$ in that environment. Permissible total PAH content in soils is $250 \mathrm{mg} \cdot \mathrm{kg}^{-1} \mathrm{DM}$, and the amount of individual compounds cannot exceed 50 $\mathrm{mg} \cdot \mathrm{kg}^{-1} \mathrm{DM}[22]$.

Benzo(a)pyrene is the main carcinogenicity indicator of a soil [23], but relative carcinogenicity indices for other PAHs have been also determined. According to these data, dibenzo(a,h)anthracene the presence of which in the tested soil was not confirmed, is more carcinogenic as compared to benzo(a)pyrene [24].

The creosote oil vapors had no significant effect on the biomass of living microorganisms in tested soils, regardless of their structure as compared to the uncontaminated soils, but only stimulated the growth of lipolytic microorganisms, as confirmed by studies of Simarrao et al. (2013) [25]. However, in the soil with a higher content of organic carbon, number of amylolytic microorganisms increased. Due to the serious threat posed to the surrounding environment by creosote oil, the biotic relationship in a contaminated environment have to be recognized.

\section{Conclusions}

1. The highest biomass and the number of proteolytic, amylolytic and lipolytic microorganisms were determined in soils from wooden railway sleepers landfill, while the lowest in soils from the railway sleeper treatment facility.

2. Creosote oil vapors had no effect on the biomass of living microorganisms in tested soils, regardless of their structure, as compared to the non-contaminated soil.

3. In soils exposed to creosote oil vapors, number of lipolytic microorganisms was significantly higher and that of proteolytic ones did not change as compared to the uncontaminated soils.

4. Creosote oil vapors, compared to the control, significantly stimulated the growth of amylolytic microorganisms in the soil with a higher organic carbon content, but did not affect their number in sandy soil.

\section{References}

1. P. Witomski, FFP, B 34, 37-44 (2003)

2. Karta charakterystyki preparatu: Centrala Obrotu Towarami Masowymi DAW- Bytom Sp. z o.o. Bytom (2010)

3. S. Moret, G. Purcaro, L. S. Conte, Sci. Total Environ. 386, 1-8 (2007)

4. Dyrektywa Komisji 2011/71/UE z dnia 26 lipca 2011 (2011)

5. S. Karlehagen, A. Andersen, C. G. Olhson, Scand. J. Work. Environ. Health 8, 26-29 (1992)

6. PN-EN 13991, (2004)

7. M. Vinas, J. Sabate, M.J. Espuny, A.M. Solanas, Appl. Environ. Microbiol. 71, 7008-7018 (2005) 
8. M. Robak, T. Boruczkowski, W. Drożdż, Z. Lazar, M. Baranowska, D. Prządo, M. Steininger, Ochr. Śr. 33, 27-33 (2011)

9. T. Janeczko, W. Bąkowski, E. Walczak, M. Robak, J. Dmochowska-Gładysz, E. Kostrzewa-Susłow, Ann. Microbiol. 65, 1097-1107 (2015)

10. J. Sabate, M. Vinas, A. M. Solanas, Chemosphere 63, 1648-1659 (2006)

11. J.P.E. Anderson, K.H. Domsch, Soil Biol. Biochem. 10, 195-221 (1978)

12. Manual DIFCO, Difco Laboratories, Detroit, Michigan, 48232 USA, 10th ed. (1984)

13. T. Krzyśko-Łupicka, T. Ciesielczuk, M. Chwałowska, Acta Sci. Pol. Biotechnol. 12, 5-18 (2013)

14. Cz. Rosik-Dulewska, T. Krzyśko-Łupicka, T. Ciesielczuk, Ł. Kręciło, Pol. J. Chem. Technol. 17, 17-22 (2015)

15. E. Elovaara, P. Heikkila, P. Pyy Mutanen, V. Riihimaki, Occup. Environ. Med. 52, 196-203 (1995)

16. C. Melber, J. Kielhorn, I. Mangelsdorf, WHO, CICADS 62 (2004)

17. J.H. McCann, B.M. Greenberg, K.R. Solomon, L. Aquat. Toxicol. 50, 265-274 (2000)

18. J. Kurzepa (red.), Chemia organizmów żywych (Radom. Tow. Nauk., Radom, 2014)

19. R. von Burg, T. Stout, J. Appl. Toxicol. 12, 153-156 (1992)

20. G. Bengtsson, N. Törneman, J.R. De Liphay, S.J. Sorensen, Environ. Microbiol. 65, 91-100 (2013)

21. S. Mukherjee, H. Juottonen, P. Siivonen, C.L. Quesada, P. Tuomi, P. Pulkkinen, K. Yrjälä, ISME J. 8, 2131-2142 (2014)

22. Dz. U. Nr 165, poz. 1359 - Rozporządzenie Ministra Środowiska z dnia 9 września 2002

23. A. Sapota, Podst. i Met. Oceny Środ. Pracy 2, 179-208 (2002)

24. I.C. Nisbet, P.K. LaGoy, RTP 16, 290-300 (1992)

25. R. Simarroa, N. Gonzáleza, L.F. Bautistab, M.C. Molina, J. Hazard. Mater. 262, 158-167, (2013) 